\title{
EFFECT OF DUKEM INHIBITOR ON AISI 1010 IN THE SECONDARY COOLING SYSTEM OF RSG GAS
}

\author{
Rahayu Kusumastuti $^{1}$, Sumaryo ${ }^{2}$, Sriyono ${ }^{1}$ \\ ${ }^{1}$ Center for Nuclear Reactor Technology and Safety, BATAN \\ ${ }^{2}$ Center for Science and Advance Material Technology,BATAN \\ Puspiptek Area,Serpong,Tagerang Selatan 15310 \\ Email: rahayu@batan.go.id \\ Diterima editor: 21 Juli 2018 \\ Diperbaiki: 14 Agustus 2018 \\ Disetujui untuk publikasi: 16 Agustus 2018
}

\begin{abstract}
EFFECT OF DUKEM INHIBITOR ON AISI 1010 IN THE SECONDARY COOLING SYSTEM OF RSG GAS. The secondary coolant of RSG GAS is an open system whose components are easy to interact with oxygen from surrounding environment to initiate corrosion. Corrosion controls are usually done by adding inhibitors. Dukem inhibitors are one alternative substitute inhibitor that may be used in the secondary cooling system of RSG GAS. The purpose of this study is to find out the optimum dukem concentration that needs to be added to RSG GAS secondary cooling system and to understand the interaction phenomenon between dukem inhibitors and AISI 1010 material. The analysis of orthophospat content as an active compound in dukem inhibitors is done by FTIR and UV-vis spectrophotometer. The phenomenon of interaction between inhibitors and material is studied by FTIR, SEM and XRD. Corrosion test with potentiostat is performed to assess the optimal concentration of dukem inhibitor which should be added. From the results of FTIR analysis, it is known that the active compounds in dukem inhibitors are ortho-phosphate. The analysis using UV-vis spectrophotometer showed that orthophospat concentration is $4.2 \mathrm{ppm}$. The SEM analysis demonstrated the presence of an inhibitor layer, which is capable of masking the surface porosity. The AISI 1010 material has better corrosion resistance when inhibitor was injected to the coolant of $150 \mathrm{ppm}$. The corrosion rate decreased by by $45.20 \%$ from 10.95 mpy to 6.02 mpy. The type of dukem inhibitor is mixed type inhibitor. Visually, corrosion product was not formed in the AISI 1010 surface during immersed in the inhibitor solution but it is clearly adhered on surface when immersed in solution added by inhibitors. It can be concluded that dukem inhibitors can be used as inhibitors in RSG GAS secondary cooling systems.

Keywords: dukem, inhibitor, corrosion, secondary cooling system, RSG GAS.
\end{abstract}

\section{ABSTRAK}

PENGARUH INHIBITOR DUKEM TERHADAP PROSES KOROSI PADA SISTEM PENDINGIN SEKUNDER RSG GAS. Sistem pendingin sekunder RSG GAS merupakan sistem pendingin resirkulasi terbuka. Komponen pendingin ini mudah berinteraksi dengan udara luar yang mengandung banyak oksigen sehingga dapat mempercepat proses korosi. Salah satu cara pengendalian korosi adalah dengan penambahan inhibitor. Inhibitor dukem merupakan salah satu alternatif inhibitor pengganti yang dapat di gunakan pada sistem pendingin sekunder. Tujuan dari penelitian ini adalah untuk mengetahui konsentrasi penambahan dukem yang optimal ke pendingin sekunder RSG GAS dan untuk mengetahui fenomena interaksi inhibitor dukem terhadap material AISI 1010. Analisis kandungan ortophospat sebagai senyawa aktif pada inhibitor dukem dilakukan dengan FTIR dan spektrofotometer uv-vis. Fenomena interaksi antara inhibitor dengan material di lakukan dengan analisis FTIR, SEM dan XRD. Uji korosi dengan potensiostat akan memberikan informasi konsentrasi optimium inhibitor dukem dan tipe inhibitor yang sebaiknya di gunakan. Dari hasil analisis FTIR diketahui bahwa kandungan senyawa aktif pada inhibitor dukem adalah senyawa orto-phospat. Analisis menggunakan spektrofotometer uv-vis memperoleh kadar ortophospat sebesar 4,2 ppm. Analisis SEM menunjukkan adanya lapisan inhibitor yang mampu menutupi porositas (spheroid) pada permukaan AISI 1010. Analisis XRD menunjukkan adanya komposisi produk korosi oksida $\mathrm{FeO}(\mathrm{OH})$ pada permukaan AISI 1010 jika tidak ditambahan inhibitor. Material AISI 1010 mempunyai ketahanan terhadap korosi yang lebih baik ketika inhibitor ditambahkan ke dalam pendingin sebesar 150 ppm. Hal ini terlihat dari penurunan kecepatan laju korosi sebesar 45,20\% dari 10,95 mpy menjadi 6,02 mpy. Analisis tafel menunjukkan inhibitor dukem merupakan jenis inhibitor campuran. Secara visual, produk korosi tidak terbentuk pada permukaan AISI 1010 ketika direndam dalam larutan inhibitor sedangkan produk korosi terlihat jelas pada specimen tanpa inhibitor. Dari penelitian ini dapat ditarik kesimpulan bahwa inhibitor dukem dapat digunakan sebagai inhibitor pada sistem pendingin sekunder RSG GAS.

Kata Kunci : dukem, inhibitor, korosi, pendingin sekunder, RSG GAS.

DOI: $10.17146 / t d m .2018 .20 .2 .4471$ 


\section{INTRODUCTION}

RSG GAS secondary cooling system is an open recirculating system [1]. This open system will potentially cause an interaction between oxygen in the environment and structure/components of the system. This interaction could lead to the possibility of corrosion [2]. Corrosion is the destruction of a material caused by the interaction with it's environmental [3]. Corrosion is a natural process that can not be prevented, but the corrosion rate can be controlled [4].

There are several methods for lowering corrosion rate, such as the selection of appropriate material design, chemical treatment, coating, cathodic protection and anodic protection. One method of controlling the corrosion rate by chemical treatment using liquid fluid is by applying inhibitor. Inhibitors are chemicals that can form a passive layer to protect metals against corrosion attacks [5].

There are 3 types of inhibitors. The first type is an anodic inhibitor, which can form a passive layer to protect metal from corrosion attack. Examples of anode inhibitors are molybdates, silicates, phosphates, borax, chromates, nitrites and nitrates. The second type is a cathodic inhibitor. This type of inhibitor, which can affect the cathodic reaction, will precipitate cathodic compounds, eg, magnesium, calcium. The third type is an absorption inhibitor. This inhibitor is an organic inhibitor with a long chain carbon system that can form a coating on the metal surface.

The control of corrosion process on the RSG GAS reactor cooling system has been done by adding additives, such as Nalco inhibitor and siskem. This is done with the aim to prevent the occurrence of corrosion, crust and also the growth of microorganisms. Siskem is a chemical that is currently added to the secondary cooling system. Previously, nalco has also been added to the system to control the corrosion, crust and growth of microorganisms.

Several studies have been conducted to determine the effect of Nalco on the corrosion rate of secondary cooling system. According to Diyah EL, the appropriate concentration of nalco inhibitor to be added to RSG secondary cooling system is $100 \mathrm{ppm}$, and the corrosion rate is $0.0873 \mathrm{mpy}$ [6]. Sofia has carried out the study of the effect of siskem to the corrosion rate on structure system and component on secondary cooling system. The effective concentration of siskem inhibitor that needs to be added to the system is $100 \mathrm{ppm}$, with the effectiveness of 35\% [7].

Dukem is one of the alternative additives that can control corrosion, crust and microorganisms. Dukem inhibitors are predicted to contain orthophospat as an active compound in inhibitors that will protect metal material from corrosion attacks. Therefore, this study was conducted with the aim to determine the performance of dukem inhibitors in the secondary cooling system RSG GAS and to know the effect of dukem to corrosion rate of carbon steel as a material on RSG GAS secondary cooling.

Dukem inhibitors contain of phosphate compounds in the form of a zinc-phosphate complex. This inhibitor serves to prevent the corrosion process and crust. Zinc in the dukem serves to reduce of the corrosion rate by raising the cathodic polarization. Cathodic polarization is done by reducing $\mathrm{O}_{2}$ in neutral or base medium, so in the polarization graph the orthophosphate compound will shifts the anodic polarization curves to be more cathodic [8]. Phosphate will bind to $\mathrm{Fe}^{3+}$ on the base metal to form $\mathrm{FePO}_{4}$ with a covalent bond which is a protective layer on the metal from the oxygen attack [9][10].

In order to know the effective concentration of dukem to be added into RSG GAS secondary cooling, several experiments were done by varying concentrations of the dukem inhibitor, i.e. 0 ppm, $75 \mathrm{ppm}, 100 \mathrm{ppm}$ and $150 \mathrm{ppm}$.

\section{METHODOLOGY}

The aim of this research is to find out the optimal concentration of addition of dukem to RSG GAS secondary cooling system and to know the phenomenon of dukem inhibitor interaction on AISI 1010 material. General stages of research as follows: Element analysis of RSG GAS secondary cooling pipe material to determine the type of pipe material. Furthermore, qualitative and 
quantitative analysis of orthophospat as active compounds in dukem inhibitors by using FTIR and $\mathrm{UV}$-vis spectrophotometer. Orthophospat will bind to Fe in the base material in a covalent bond to form a protective layer from the corrosion attack. The phenomenon of forming a protective layer was analyzed using SEM. The orthophosphate performance in coating the metal was proven by the absence of corrosion products. This was analyzed using XRD. The protective layer will protect the metal from corrosion attack, which is indicated by a decrease in corrosion rate. It will be analysis with a potentiostat. The analysis stages are as follows:

1. Analysis of elements in RSG GAS secondary pipe material using spectroscopy. This analysis is conducted to determine the type of material used in the secondary system piping so that the corrosion resistance of the material will be evaluated.

2. Fourier Transform Infrared Spectroscopy (FTIR) analysis of inhibitors to predict functional groups in active compounds. This analysis uses the FTIR merk Shimadzu 8400S.

3. Analysis of inhibitor content using UV-Vis to determine the main compound. This test is performed to ensure that the main content in the dukem is orthophosphate.

4. SEM Testing (Scanning Electron Microscope) performed on the material before and after immersion of material on the solution. So will be known that the inhibitor effect on the corrosion process occurs on carbon steel.

5. X-ray diffraction analysis (XRD) was performed to determine the corrosion product formed on spescimen surface. Crystal structure on the surface of the material indicate the effect of inhibitors The influence of inhibitors will be known by the formation of new compounds on the surface of the material. XRD Testing uses XRD Pan Analitycal and analysis using Jade software.

6. A corrosion test is performed using EG \& G Potensiostat / Galvanostat Model 273. The corrosion test is performed by varying the concentration inhibitor on puspiptek water as a solution at room temperature. Preparation of corrosion sample according to ASTM G-36 standard.

\section{RESULT AND DISCUSSION}

\section{Analysis of element pipe material.}

The RSG GAS secondary cooling pipe material has been tested for its elemental content with the results shown in Table 1. The main elements of the carbon steel material are $\mathrm{Fe}(98.900 \%)$, and the C content is $0.109 \%$. Based on standard materials it is known that this material is AISI 1010. AISI 1010 has very low carbon content, so it can be categorized into materials that have low strength but have high ductility.

Table 1. The content of RSG GAS secondary cooling pipe material

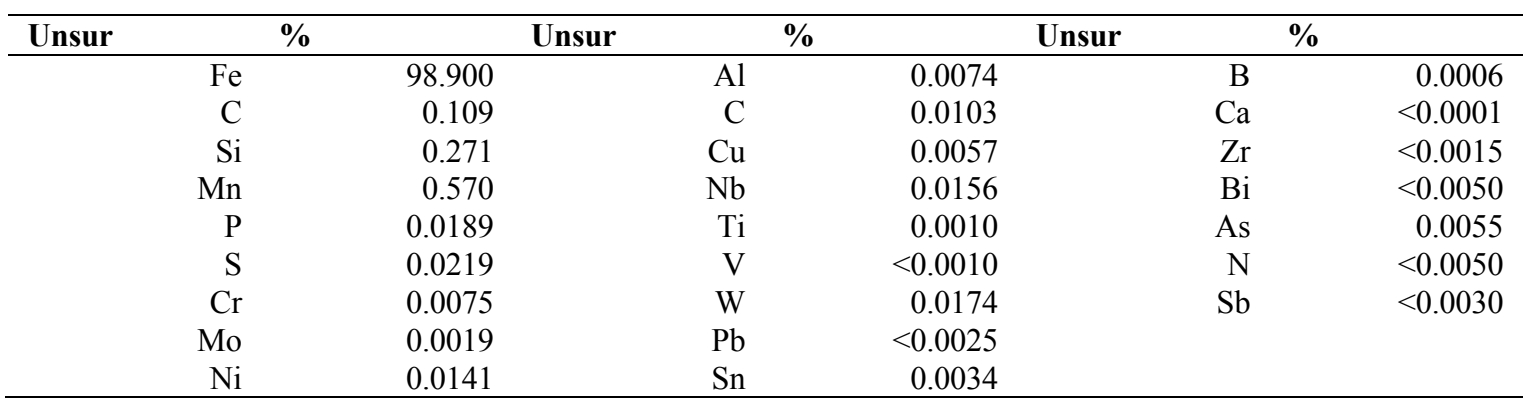

\section{FTIR Analysis}

FTIR analysis is performed on base materials and inhibitors. This analysis is done to know the functional group. The functional groups are used to predict the inhibitory ability of binding to carbon steel [11-13]. The results of FTIR analysis on carbon steel material are shown in Figure 1. 


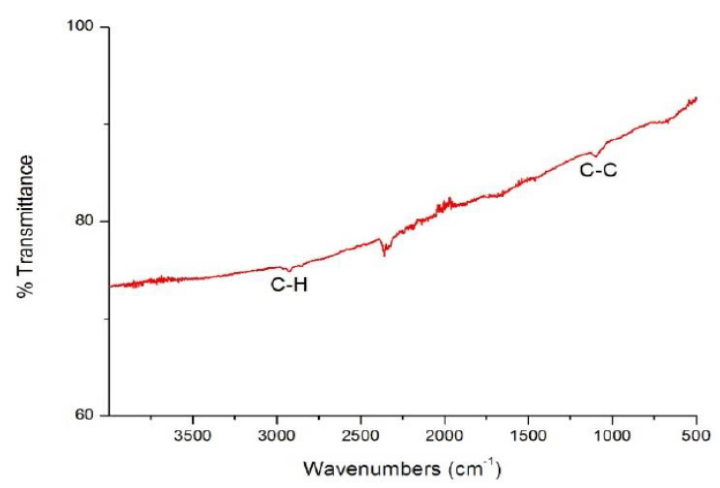

Figure 1. FTIR results test on AISI 1010 steel

Figure 1 shows the presence of function group on specimens. There are $\mathrm{C}-\mathrm{H}$ (alkanes) and C-C (also alkanes). FTIR results in inhibitors are shown in Figure 2. Based on these data we see the presence of $\mathrm{O}-\mathrm{H}$ (hydroxyl), $\mathrm{C}-\mathrm{O}$ ( $\beta$ diketon), and $\mathrm{PO}_{4}{ }^{3-}$ (phosphat) groups as the dominant group is a phosphate. The phosphate is the active compound of the inhibitor. The formula of the active compound in inhibitor is $\mathrm{Zn}_{3}\left(\mathrm{PO}_{4}\right)_{2}$, thus FTIR testing is able to prove that there is a corresponding analysis result with chemical data from the supplier.

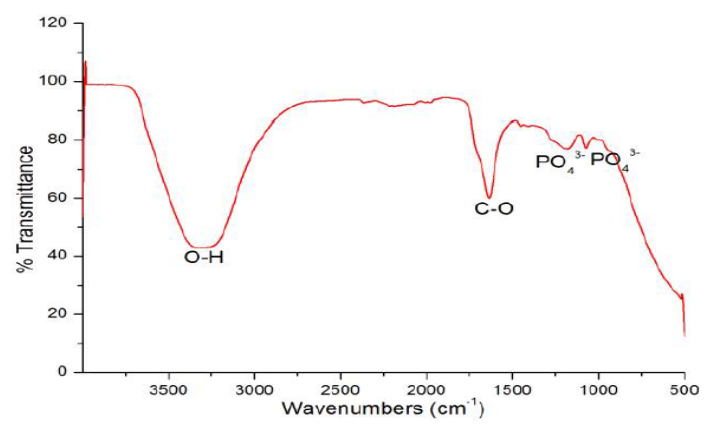

Figure.2. FTIR results test on dukem inhibitors

Spesciment was immersed in dukem inhibitors and then analyzed using FTIR. The results of FTIR analysis of specimens which have been immersed in the inhibitor are shown in Figure 3. In the specimens that have been soaked dukem inhibitor found the functional group O-H (hydroxyl), C-O ( $\beta$ diketon), and $\mathrm{PO}_{4}{ }^{3-}$ (phosphate).

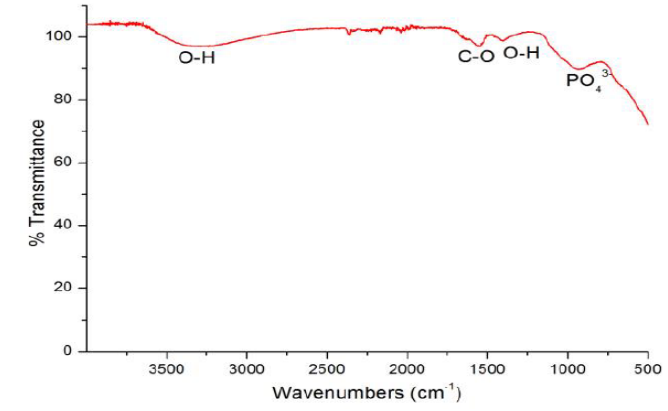

Figure 3. FTIR results test on the specimens that have been immersed in solution with the addition of a dukem inhibitor.

Figure 3 shows a graphic change from Figures 1 and 2. After the specimen is immersed in the inhibitor, there will be a bond between the two by forming a covalent bond. It is seen that there is absorption in infrared spectra, show the presence of $\mathrm{OH}$ and $\mathrm{PO}_{4}$ functional groups. The adsorption process occurs because of the bonding of Fe element in carbon steel with phosphate. Because of this bond then the corrosion process can be inhibited. The ortho-phosphate compound is an active phospate compound of the main content of a dukem inhibitor. ortho-phosphate binds with zinc to 
form zinc-phospate complexes. It's will interact with $\mathrm{Fe}$ to form $\mathrm{Fe}_{3}\left(\mathrm{PO}_{4}\right)_{2}$. These complex compounds form a layer on the surface of specimens to inhibits the corrosion process.

\section{Analysis of ortho-phosphate content in dukem inhibitors.}

Quantitative analysis of orthophospat was carried out using an ultrasonic-vissible spectrophotometer Model Carry 50, the orthophosphate concentration in dukem was $4.2 \mathrm{ppm}$. This means that in $1000 \mathrm{~mL}$ of solution there is $4.2 \mathrm{mg}$ of phosphate.

\section{XRD Analysis and Visual Observation}

XRD analysis is used for analysis of the composition of phases in the material as well as the characterization of crystals [13]. XRD analysis was performed on 2 specimens which had been immersed in RSG GAS secondary water with addition of $150 \mathrm{ppm}$ dukum inhibitor and without inhibitor. It's for determine the effect of inhibitor on corrosion product formation on material surface. XRD results are analyzed using Jade software as shown in Figure 4. The figure 4, known that the dominant corrosion product composition on the specimen surface is $\mathrm{FeO}(\mathrm{OH})$ oxide. Based on the two graphs produced, there are two different peaks of $\mathrm{FeO}(\mathrm{OH})$ peaks, this indicates different oxygen levels. Differences in oxygen levels differ greatly between specimens with inhibitors and without inhibitors. With the addition of dukem inhibitors it can be concluded that there is significant reduction of corrosion products on the surface. The reduction of corrosion products occurs because the corrosion process that occurs is inhibited by dukem inhibitors.

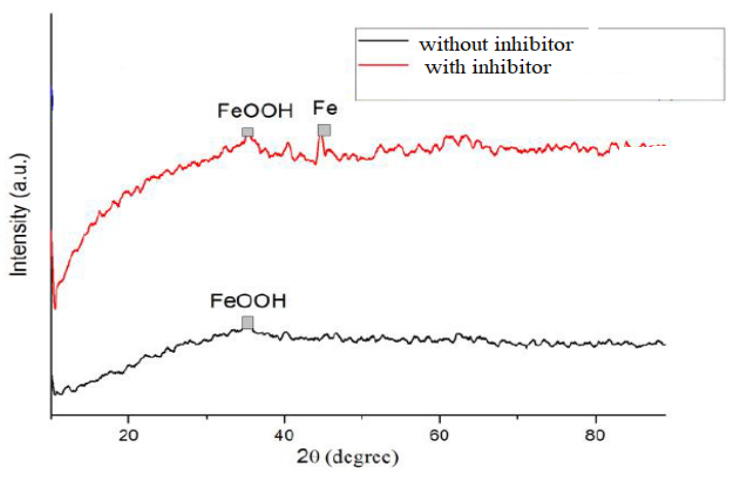

Figure 4. XRD result analysis on specimens

The visual observation results are shown in Figure 5. Both images are portraits of AISI 1010 specimens immersed for 7 days without inhibitors 5a, known the corrosion product. Specimens immersed in RSG secondary cooling system with the addition of inhibitor, like in figure $5 \mathrm{~b}$. On the surface of specimens without inhibitors there is a significant corrosion product. Corrosion products can be seen on the surface of speciment with an orange colour. While the speciment surface with added inhibitor will have a natural colored (silver) which means there is no corrosion product.
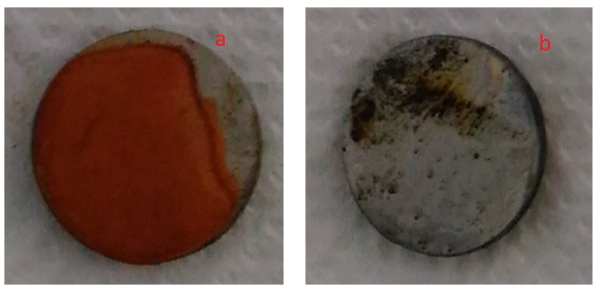

Figure 5. Visual observation of AISI 1010 carbon steel (a) the specimen is immersed without inhibitor, (b). the specimen was soaked with the addition of an inhibitor

\section{SEM Analysis}

The SEM test is used to examine the surface morphology of a material [13][14]. The SEM analysis was performed on 2 samples ie AISI 1010 specimens which were immersed without 
inhibitor and AISI 1010 which was immersion on inhibitor. Figure 6 shows the SEM results analysis on AISI 1010 without inhibitors. Figure. 6a is a 100X magnification image showing a slight porosity on the surface of AISI 1010. Figure. $6 \mathrm{~b}$ is a $500 \mathrm{X}$ magnification indicating the presence of spheroidal spheres AISI 1010 surfaces without immersion on inhibitors, that indicates a representation of base material with porosity which, if enlarged as a spheroid. This porosity or spheroid facilitates interaction with oxygen so that easily occurs corrosion process.

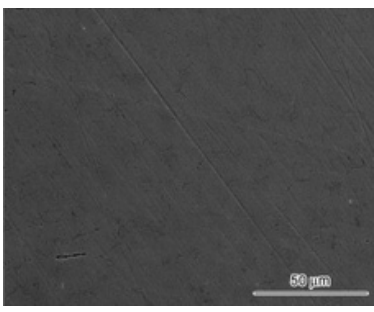

(a)

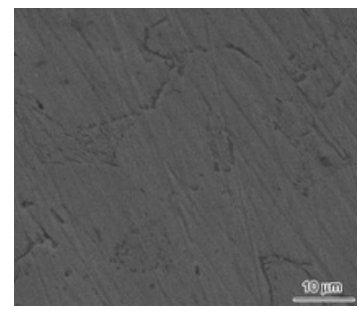

(b)

Figure 6. SEM analysis on AISI 1010 specimen without using inhibitor (a) 100X magnification image showing a slight porosity on the surface of AISI 1010 and (b) $500 \mathrm{X}$ magnification indicating the presence of spheroidal spheres AISI 1010 surfaces

The SEM analysis of a specimen that has been immersed in secondary cooling water with the added inhibitor is shown in Figure 7. Figure 7a and 7b show a morphology of the specimen surface. On the surface of AISI 1010 no corrosion product was found. Thus it can be concluded that the dukem inhibitor with the active ingredient zincphosphate forms a protective layer on the surface of AISI 1010. This protective layer on the surface porosity thus preventing oxidation corrosion [15][16].

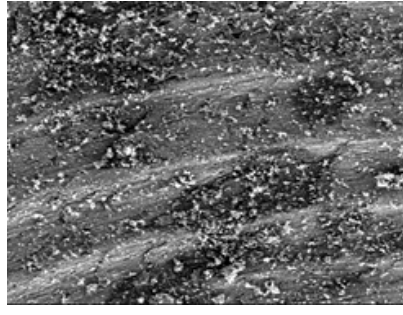

(a)

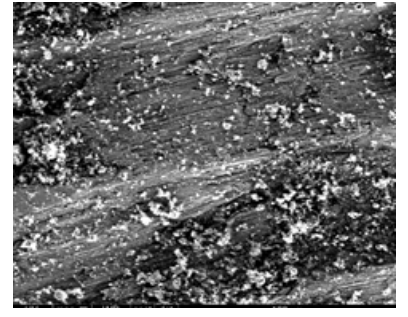

(b)

Figure 7. SEM analysis on AISI 1010 specimen with inhibitor (a) $100 \mathrm{x}$ magnification and (b) 500X magnification

\section{Corrosion Rate Analysis}

Spesciment corrosion rate was conducted using EG \& G Potensiostat / Galvanostat Model 273. The medium used in corrosion analysis was secondary cooling water with and without addition of inhibitor. Addition of inhibitor varied from 75, 100 and $150 \mathrm{ppm}$. The Tafel polarization method is used for the analysis of the corrosion rate[17, 18]. The Tafel analysis are shown in Figure. 8, while the corrosion rate results are shown in Table 4 and Figure 8. In Figure 8 it is known that with the addition of inhibitor from 0 to $100 \mathrm{ppm}$, that indicates the shift of the polarization curve towards the anodic. While the addition of inhibitor concentration as much as $150 \mathrm{ppm}$ showed a cathodic curve shift. It can thus be concluded that dukem inhibitors are mixed type inhibitors [8]. The process of cathodic inhibition occurs due to the formation of the zinc hydroxide layer, whereas the anodic passage occurs because the reaction of the orthophosphate group with iron $(\mathrm{Fe})$ forms a layer of iron phosphate due to the presence of dissolved oxygen. 


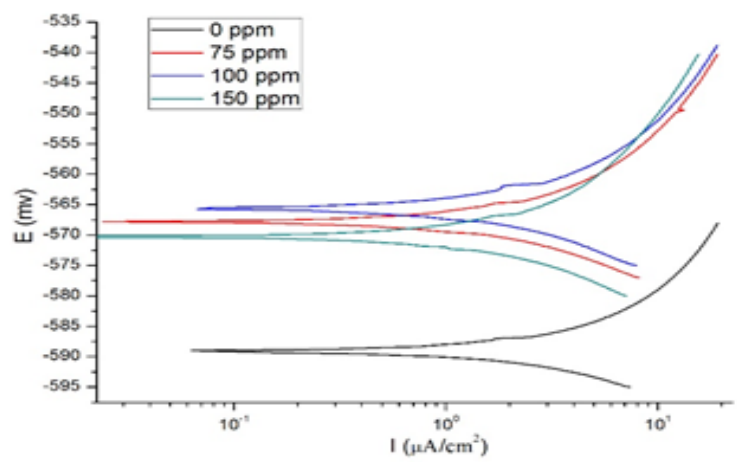

Figure 8. AISI 1010 Tafel polarization curve on secondary cooling water with the addition of $0 \mathrm{ppm}, 75$ ppm, $100 \mathrm{ppm}$, and $150 \mathrm{ppm}$ inhibitors.

The corrosion rate of the specimens was determined by the corrosion current (I-corr) and the corrosion stress (Ecorr) shown in Table 4. Both Icorr and Ecorr parameters were obtained based on Tafel polarization analysis. The greatest corrosion rate occurred in the specimens without added inhibitors of 10.95 mpy, while the smallest corrosion rate in the specimens was immersed in secondary cooling water with the addition of 6.02 mpy inhibitor. The greater concentration of added dukem inhibitor, the lower corrosion rate occurring in AISI 1010.

Table 4. Corrosion rate of AISI 1010 specimens on secondary cooling water with and without inhibitor

\begin{tabular}{ccccrr}
\hline $\begin{array}{c}\text { Inhibitor } \\
\text { Type }\end{array}$ & $\begin{array}{c}\text { Inhibitor } \\
\text { Concentration } \\
(\mathrm{ppm})\end{array}$ & -Ecorr $(\mathrm{mv})$ & $\begin{array}{c}\text { Icorr } \\
\left(\mu \mathrm{A} / \mathrm{cm}^{2}\right)\end{array}$ & $\begin{array}{c}\text { Corrosion Rate } \\
(\mathrm{mm} / \mathrm{yr})\end{array}$ & $\begin{array}{c}\text { efficiency } \\
\text { inhibitor }(\%)\end{array}$ \\
\hline \multirow{3}{*}{ Dukem } & 0 & 588.96 & 23.73 & 10.95 & - \\
& 75 & 567.52 & 15.70 & 7.24 & 33.88 \\
& 100 & 565.43 & 15.20 & 7.01 & 35.98 \\
& 150 & 569.91 & 13.05 & 6.02 & 45.20 \\
\hline
\end{tabular}

\section{CONCLUSION}

The results of the analysis, it can be concluded that dukem is a good type of inhibitor to be used to prevent corrosion in RSG GAS secondary cooling pipe material. This can be seen in the SEM, XRD analysis. SEM analysis shows that the inhibitor will form a protective layer on the surface of the specimen to protect from corrosion process. This is reinforced by XRD analysis on specimens without inhibitor treatment, the dominant corrosion product on the specimen surface is the formation of $\mathrm{FeO}(\mathrm{OH})$ oxide.

\section{ACKNOWLEDGMENTS}

The authors would like to thank Ms. Diyah EL and Mr.Santosa (PRSG) for their assistance in providing experimental materials. This research is held on the support of DIPA PTKRN fund in 2017. The authors appreciate also to PSTBM-BATAN upon permission to use its laboratory equipment.

\section{DAFTAR PUSTAKA}

1. Ratnawati E., Lestari D.E. Study of Primary Coolant Impurities in Reactor Rsg Gas After 30. 2018.:17-24.

2. Kusumastuti R. Water Chemistry Analysis In Secondary Cooling System RSG. Sigma Epsil. 2016. 20(2):57-63. 
3. Zayed A., Garbatov Y., Guedes Soares C. Corrosion degradation of ship hull steel plates accounting for local environmental conditions. Ocean Eng. 2018. 163(April):299-306.

4. Fischer K.B., Daga A., Hatchell D., Rochelle G.T. MEA and Piperazine Corrosion of Carbon Steel and Stainless Steel. Energy Procedia. 2017. 114(November 2016):1751-64.

5. Kusumastuti R., Pramana R.I., Soedarsono J.W. The use of morinda citrifolia as a green corrosion inhibitor for low carbon steel in 3.5\% NaCl solution. AIP Conf. Proc. 2017. 1823

6. Diah erlina lestari D. Pengaruh inhibitor korosi terhadap bahan sistem pendingin sekunder RSG-GAS. Pros. Has. Penelit. P2TRR. 2004.:334-45.

7. Sofia Loren Butar-butar and Geni Rina Sunaryo Analisis Mekanisme Pengaruh Inhibitor Siskem Pada Material Baja Karbon. Pros. Semin. Nas. Ke-18 Teknol. Dan Keselam. Pltn Badan Tenaga Nukl. Nas. 2011.(0854-2910):559-66.

8. Safitra E.R., Lestari D.E., Rilyanti M., Kimia S.T., Kimia J., Lampung U. Orthofosfat Dan Seng Sebagai Parameter Kendali Korosi Pada Sistem Pendingin Sekunder Rsg-Gas. J. Sci. Appl. Technol. 2017. 1(2):102-5.

9. Yohai L., Vázquez M., Valcarce M.B. Phosphate ions as corrosion inhibitors for reinforcement steel in chloride-rich environments. Electrochim. Acta. 2013. 102:88-96.

10. Bastidas D.M., Criado M., La Iglesia V.M., Fajardo S., La Iglesia A., Bastidas J.M. Comparative study of three sodium phosphates as corrosion inhibitors for steel reinforcements. Cem. Concr. Compos. 2013. 43:31-8.

11. Alaneme K.K., Olusegun S.J., Adelowo O.T. Corrosion inhibition and adsorption mechanism studies of Hunteria umbellata seed husk extracts on mild steel immersed in acidic solutions. Alexandria Eng. J. 2016. 55(1):673-81.

12. Fawzy A., Abdallah M., Zaafarany I.A., Ahmed S.A., Althagafi I.I. Thermodynamic, kinetic and mechanistic approach to the corrosion inhibition of carbon steel by new synthesized amino acids-based surfactants as green inhibitors in neutral and alkaline aqueous media. J. Mol. Liq. 2018. 265:276-91.

13. Alibakhshi E., Ghasemi E., Mahdavian M. Sodium zinc phosphate as a corrosion inhibitive pigment. Prog. Org. Coatings. 2014. 77(7):1155-62.

14. Fytianos G., Ucar S., Grimstvedt A., Svendsen H.F., Knuutila H. Corrosion evaluation of MEA solutions by SEM-EDS, ICP-MS and XRD. Energy Procedia. 2016. 86(1876):197204.

15. Ghaffari M.S., Naderi R., Sayehbani M. The effect of mixture of mercaptobenzimidazole and zinc phosphate on the corrosion protection of epoxy/polyamide coating. Prog. Org. Coatings. 2015. 86:117-24.

16. Shi C., Shao Y., Wang Y., Meng G., Liu B. Influence of submicron-sheet zinc phosphate synthesised by sol-gel method on anticorrosion of epoxy coating. Prog. Org. Coatings. 2018. 117(September 2017):102-17.

17. Tamilselvi M., Kamaraj P., Arthanareeswari M., Devikala S. Nano zinc phosphate coatings for enhanced corrosion resistance of mild steel. Appl. Surf. Sci. 2015. 327:21825 .

18. Jadhav A.J., Holkar C.R., Pinjari D. V. Anticorrosive performance of super-hydrophobic imidazole encapsulated hollow zinc phosphate nanoparticles on mild steel. Prog. Org. Coatings. 2018. 114(April 2017):33-9. 